

\title{
Decolorization of Sulfonated Azo Dye Methyl Orange by Bacterial Species
}

Ramesh S. Masarbo*

Assistant Professor, Department of Chemistry, A V Patil Degree College of Arts, Science \& Commerce, Aland, Gulbarga, Karnataka, India

*Corresponding author

\begin{tabular}{|c|c|}
\hline KEYWORDS & A B S T R A C $T$ \\
\hline $\begin{array}{l}\text { Azo dyes, } \\
\text { Decolorization, } \\
\text { Degradation, } \\
\text { Bacillus sp., } \\
\text { Textile dye. }\end{array}$ & $\begin{array}{l}\text { Synthetic dyes are extensively used in textile industries and other industries. } \\
\text { Methyl orange is one such azo dye, which is widely used in textile industries } \\
\text { and also as an indicator in chemical laboratories. This study focuses on the } \\
\text { capability of Bacillus sp. Strain AK } 1 \text { to decolorize Methyl Orange dye. } \\
\text { Various parameters like time course, initial dye concentration, pH and } \\
\text { temperature were optimized to achieve maximum decolorization of the dye. } \\
\text { The bacterium exhibited remarkable color removable capability over a wide } \\
\text { range of dye concentration, pH and temperature. The bacterial strain } \\
\text { decolorized Methyl orange }(200 \mathrm{mg} / \mathrm{l}) \text { upto } 85 \% \text { in } 24 \text { hours of incubation at } \\
\text { pH7 and temperature } 37^{\circ} \mathrm{c} \text {. The efficiency decreased with the increase in } \\
\text { initial dye concentration. The pH also had a great impact upon the } \\
\text { decolorizing ability. }\end{array}$ \\
\hline
\end{tabular}

\section{Introduction}

Ever since the beginning of mankind, people have been using colorants for painting and dyeing their surroundings, their skins and their cloths. With the rapid industrialization, now there are more than $1,00,000$ commercially available dyes and $7 \times 10^{5}$ metric tons of dyestuffs are produced annually (Wong and Yu, 1999). Dyes are used in textile industry, leather tanning industry, paper industry, food industry, hair coloring and cosmetics. Azo dyes constitute largest group of synthetic dyes. These are extensively used for dyeing fabrics in textile industries. The textile dyeing generates a large amount of waste water containing dyes and represents one of the largest causes of water pollution (Bhatti, et al., 2008), as $10-15 \%$ of dyes are lost in the effluent during the dyeing process. It is very difficult to treat textile industry effluents because of their high BOD, COD, heat, color, $\mathrm{pH}$ and presence of metal ions (Anjali, et al., 2007). Azo dyes are used increasingly in industries. Most azo dyes are toxic, carcinogenic and mutagenic (Pinherio et al., 2004). In addition to this, the dyes 
may significantly affect photosynthetic activity of aquatic life by decreasing light absorption and also may be toxic due to the presence of aromatics or heavy metals (Saratale et al., 2006; Vajayanant and Hemapriya, 2013). Traditional waste water treatment methods have proven to be ineffective because of the chemical stability of these pollutants. Azo bonds present in these dyes are resistant to breakdown with the potential for the persistence and accumulation in the environment (Telke Amar et al). A wide range of methods have been developed for the removal of synthetic dyes from waste waters. Bioremediation of textile effluents through microorganisms has been of considerable significance since it is inexpensive, eco-friendly and produces less amount af sludge. A wide variety of microorganisms are reported to be capable of decolorization of azo dyes. Considering the advantages and potential applications of bioremediation processes in textile effluent treatment, the present study deals with the bioremediation of Methyl Orange, a synthetic sulfonated textile azo dye by bacterial strain.

\section{Materials and Methods}

\section{Bacterial Culture}

Bacillus sp. Strain AK1 was previously isolated from dye contaminated soil sample collected around the Dyeing Industries, Solapur, India. This strain was capable of decolorizing azo dyes efficiently. This strain was grown under static condition at room temperature in Luria-Bertani (LB) broth.

\section{Dyes and Media}

The azo dye Methyl Orange was procured from sd fine chemicals ltd. Dye was checked for its color, solubility in water and absorption maximum. The mineral salt medium was prepared with following composition (g/l): $\mathrm{K}_{2} \mathrm{HPO}_{4}(6.3), \mathrm{KH}_{2} \mathrm{PO}_{4}$ (1.8), $\mathrm{NaCl}(5), \mathrm{NH}_{4} \mathrm{NO}_{3}(1), \mathrm{MgSO}_{4} \cdot 7 \mathrm{H}_{2} \mathrm{O}$ (0.1), $\mathrm{MnSO}_{4}(0.1), \mathrm{CaCl}_{2} .2 \mathrm{H}_{2} \mathrm{O}$ (0.1), $\mathrm{FeSO}_{4} .7 \mathrm{H}_{2} \mathrm{O}(0.1), \mathrm{NaMoO}_{7} .7 \mathrm{H}_{2} \mathrm{O}(0.006)$. The final $\mathrm{pH}$ of the medium was adjusted to 7.2. The mineral salt medium was supplemented with yeast extract $(2.5 \mathrm{~g} / \mathrm{l})$, peptone $(5 \mathrm{~g} / \mathrm{l})$ and Methyl orange dye $(200 \mathrm{mg} / \mathrm{l})$. All the chemicals used in this study were of analytical grade.

\section{Decolorization Experiments}

The decolorization experiments were performed in $250 \mathrm{ml}$ Erlenmeyer flasks containing MS medium. Methyl Orange $(200 \mathrm{mg} / \mathrm{l})$ was added to decolorization medium and inoculated with $2 \mathrm{ml}$ of cultures broth. The flasks were incubated at $40^{\circ} \mathrm{c}$ under static conditions till the decolorization was completed.

\section{Analytical methods for dye decolorization studies}

The samples were withdrawn at different time intervals and analyzed for decolorization efficiency. Decolorization was quantitatively analyzed by measuring the absorbance of the supernatant using a UV-Visible spectrophotometer at maximum wavelength. $\lambda_{\max }$ for Methyl Orange was $465 \mathrm{~nm}$. Decolorization percentage was calculated by using the equation

$\%$ Decolorization

$=\frac{\text { Initial absorbance-Final absorbance }}{\text { Initial absorbance }} \times 100$

\section{Study of Physico-chemical parameters}

Decolorization ability of strain AK1 on Methyl Orange was studied at different $\mathrm{pH}$ 
(5-9), temperature values $\left(15-50^{\circ} \mathrm{C}\right)$, dye concentration $(200-1000 \mathrm{mg} / \mathrm{l})$ etc. The effect of these physicochemical factors was studied. It was observed that $\mathrm{pH} 7.2$ and temperature $37^{\circ} \mathrm{c}$ were found to be optimal for the decolorization activity. Effect of other factors was studied at $\mathrm{pH} 7.2$ and temperature $37^{\circ} \mathrm{C}$.

\section{Results and Discussion}

\section{Time course for decolorization of Methyl Orange}

At an early 6 hours of incubation $10 \%$ of decolorization was exhibited by the strain AK1. It showed $30 \%$ decolorization in 12 hours, $79 \%$ decolorization in 24 hours and $85 \%$ decolorization in 30 hours. The experiment was carried out by taking $200 \mathrm{mg} / \mathrm{l}$ dye at $\mathrm{pH} 7$ and temperature $37^{\circ} \mathrm{C}$.

\section{Effect of initial dye concentration}

The decolorization of Methyl orange was carried out at different initial dye concentrations from $200 \mathrm{mg}$ to $1000 \mathrm{mg} / \mathrm{l}$. The decolorization percentage of Methyl orange decreased with increase in the concentration of the dye under static conditions. Lower decolorization percentage at high dye concentration was reported. This might be due to the inhibitory effects of high dye concentration.

\section{Effect of pH on dye decolorization}

The effect of $\mathrm{pH}$ on the decolorization of Methyl Orange was determined over a wide range of $\mathrm{pH}$ from 4 to 9 . The strain showed maximum dye decolorization at $\mathrm{pH}$ 7. At this optimum $\mathrm{pH}$, the strain showed $85 \%$ decolorization of Methyl Orange. No decolorization was observed at $\mathrm{pH} 4$. The strain showed $10 \%, 77 \%, 80 \%$ and $74 \%$ decolorization at $\mathrm{pH} 5, \mathrm{pH} 6, \mathrm{pH} 8$ and $\mathrm{pH} 9$ respectively.

\section{Effect of temperature on dye decolorization}

The decolorization of the dye was tested for a wide range of temperatures from 15 to $50^{\circ} \mathrm{c}$. Increase in decolorization of Methyl Orange was observed with the increase in temperature and it was optimum at $37^{\circ} \mathrm{c}$. Further increase in the temperature resulted in decreased percentage of decolorization. The decrease in dye decolorizationat high temperature can be attributed to the decline in microbial activity that led to the inactivation of the enzyme and eventually loss of cell viability.



Figure.1 Effect of incubation time on decolorization of Methyl orange 
Int.J.Curr.Res.Aca.Rev.2016; 4(5): 172-178

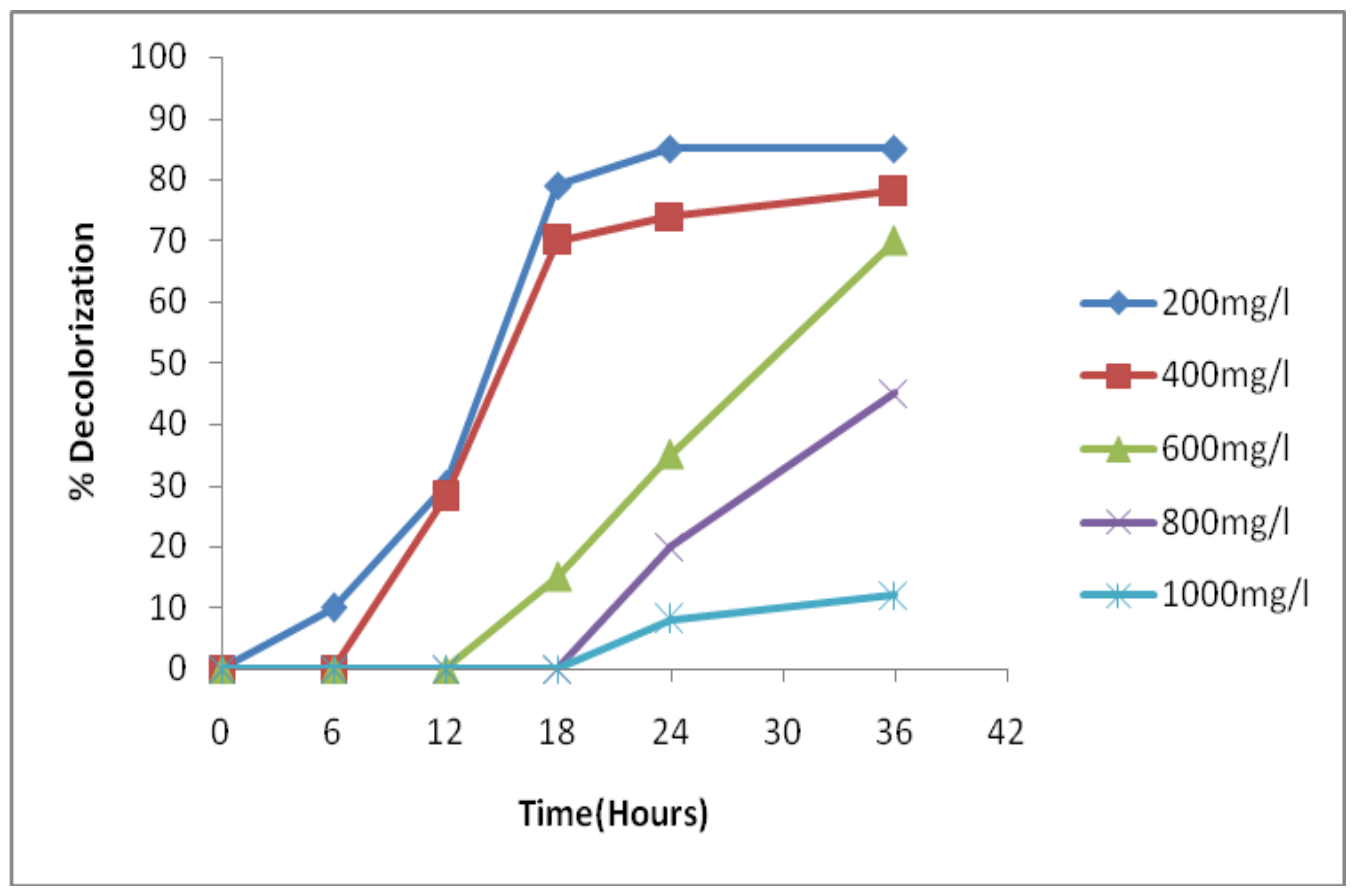

Figure.2 Effect of dye concentration on decolorization of Methyl orange

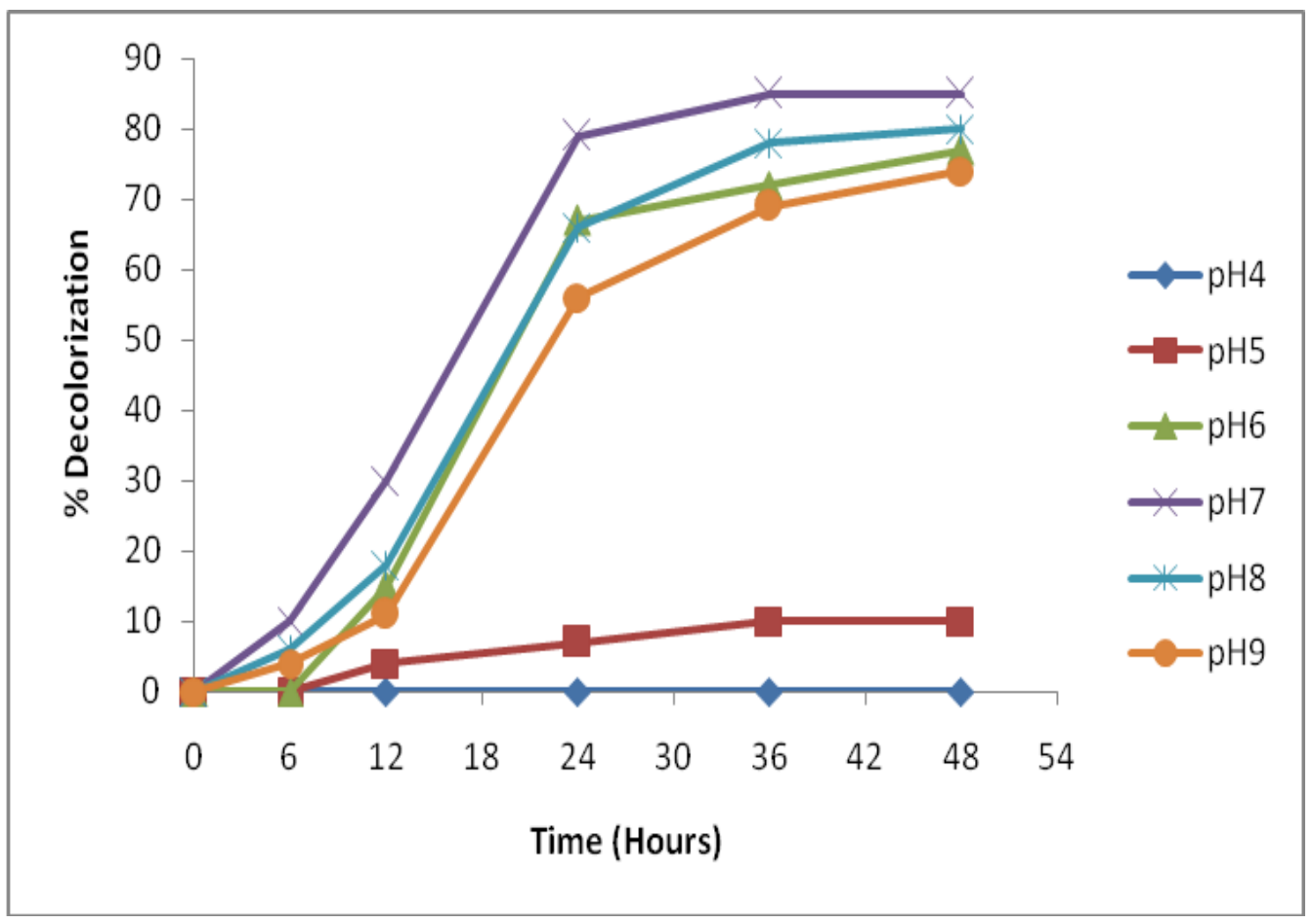

Figure.3 Effect of $\mathrm{pH}$ on decolorization of Methyl orange 


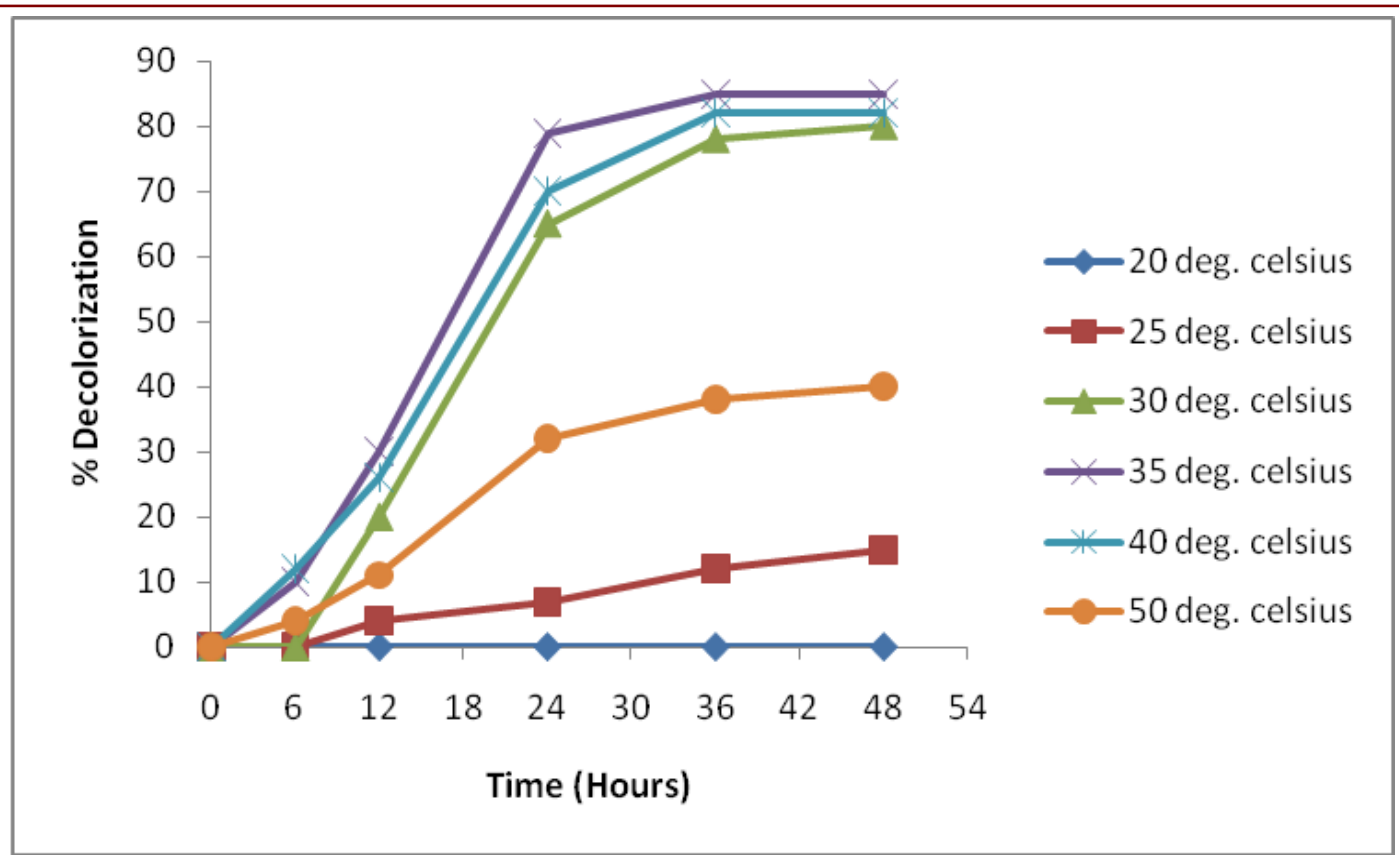

Figure 4: Effect of temperature on decolorization of Methyl orange

\section{Conclusion}

Bacterial decolorization proves to be a very efficient method for complete decolorization of Methyl Orange. The purpose of this study is to investigate the decolorization of Methyl Orange by Bacillus sp. Strain AK1. The bacteria successfully decolorize Methyl orange. Most markedly the strain could effectively decolorize the dye, Methyl orange over dye concentrations of $200-800 \mathrm{mg} / \mathrm{l}, \mathrm{pH}$ of $5-9$ and temperature $20-50^{\circ} \mathrm{c}$. Decolorization with Bacillus sp. AK1 yields high maximum decolorization activity of $85 \%$ at dye concentration 200mg/l, pH 7 and temperature $37^{\circ} \mathrm{c}$. It can be concluded that Bacillus sp. AK1 is highly promising and suitable microorganism for use in the treatment of textile waste water.

\section{Acknowledgements}

The author is highly grateful to UGC for the financial support under the scheme of Minor Research Project. Also thankful to
Gulbarga University, Gulbarga and Principal and management of HKES's A. V. Patil College, Aland for providing the infrastructure facility for the research work.

\section{References}

Anjali, P., Poonam, S., Leela, L. 2007. Bacterial decolorization and degradation of azo dyes, Int. Biodet. Biodegr., 59: 73-84.

Anjaneya, O., YogeshSouche, S., Santhoshkumar, M., Karegoudar, T.B. 2011. Decolorization of sulfonatedazo dye Metanil Yellow by newly isolated bacterial strain: Bacillus sp. Strain AK1 and Lysini Bacillus sp. strain AK2, J. Hazardous Materials, 190: 351-358.

Baljeet Singh Saharam, Poonam Ranga. 2011. Optimization of culture conditions for decolorization of textile azo dyes by Bacillus subtilis spr42 under submerged fermentation, $A d v$. Biotechnol. Res., 2(1): 148-153. 
Bhatti, H.N., Akram, N., Asgher, M. 2008. Optimization of culture conditions for enhanced decolorization of Cibacron red FN-2BL Schizophyllum commune IBL-6, Appl. Biochem. Biotecnol., 149: 255-264.

Chang, J.S., Kuo, T.S. 2000. Kinetics of bacterial decolorization of azo dye with Escherichia coli NO3, Biores. Technol., 75: 107-111.

Chang, J.S., T.S. Kuo, Y.P. Chao, J.Y. Ho, Lin, P.J. 2000. Azo dye decolorization with a mutant Escherisia coli strain, Biotechnol. Lett., 22: 807-812.

Dawkar, V.V., U.U. Jadhav, D.P. Tamboli, S.P. Govindwar. 2010. Efficient industrial dye decolorization by Bacillus sp. VUS with enzyme system, Ecotoxicol. Environ. Saf., 73: 6961703.

Gupta, V.K., Rastogi, A., Saini, V.K., Jain, N. 2006. Biosorption of Copper (II) from aqueous solutions by spirogyra species, J. Colloid and Interface Sci., 296: 59-63

Jadhav, S.U., M.U. Jadhav, A.N. Kagalkar, S.P. Govindwar. Decolorization of Brilliant Blue $G$ dye mediated by degradation of the microbial consortium of Galactomyces geotrichum and Bacillus sp., J. Chin. Inst. Chem. Eng.

Kapilkumar, M.G., T.R. Dastidar, Sree Krishnan. 2009. Effect of process parameters on aerobic decolorization of reactive azo dye usingmixed culture, World Acad. Sci. Eng. Technol., 58: 963-965.

Parshetti Ganesh, Kalme Satish, Saratale Ganesh, Govindwar Sanjay. 2006. Biodegradation of Malachite Green by Kocuriarosea MTCC 1532 Acta. Chim. Slov., (53): 492-498.

Patil, P.S., U.U. Shedbalkar, D.C. Kalyani, J.P. Jadhav. 2008. Biodegradation of Reactive Blue 59 by isolated bacterial consortium of PMB11, J. Ind. Microbiol. Biotechnol., 35: 1181-1190.

Pearce, C.I., J.R. Lioyd, J.T. Gutherie. 2003. The removal of color from textile wastewater using whole bacterial cells: a review, Dyes Pigments, 58: 179-186.

Pinherio, H.M., Touraud, E., Tomas, O. 2004. Aromatic amines from azo dye reduction: status review with emphasis on direct UV spectrometric detection in textile industry waste water, Dyes and Pigments, 61(2): 121-139.

Ponraj, M., Gokila, K., Vasudeo Zambare. 2011. Bacterial decolorization of textile dye Orange 3R, Int. J. Adv. Biotechnol. Res., ISSN 0976-2612, 2(1): 168-177.

Saratale, R.G., G.D. Saratale, J.S. Chang, S.P. Govindwar. 2009. Decolorization and biodegradation of textile dye Navy Blue HER by Trichosporonbiegelli NCIM-3326, J. Hazard. Mater., 166: 1421-1428.

Telke Amar, KalyaniDayanand, JadhavJyoti, Govinwar Sanjay. 2007. Kinetics and Mechanism of Reactive Red 141 degradation by a bacterial isolate Rhizobium radiobacter MTCC 8161. Aela Chim. Slov., 55: 320-329.

Toshiaki, N.K., S. Mifumi, N. Nobuhiko, C. Thalerng, N. Tadaatsu. 1999. Decolorization of malasses wastewater by Bacillus sp. Under thermophilic and anaerobic conditions, J. Biosci. Bioenerg., 87: 119-121.

Verma, P., D. Madamwar. 2003. Decolorization of synthetic dyes by a newly isolated strain of Serratiamaerascens, World J. Microbiol. Biotechnol., 19: 615-618.

Wong, P., Yuen, P. 1996. Decolorization and biodegradation of Methyl red by Klebsiella pneumoniae RS-13, Water Res, 30(7): 1736-1744.

Yatome, C., K.T. Maitri, B.C. Bhattacharya. 1993. Degradation of crystal violet by 
Nocardia crallina, Appl. Microbiol. Biotechnol., 38: 565-569.

Yuan, Y., Wen, Y.Z., Li, Y.Z., Luo, S.Z. 2006. Treatment of wastewater from dye manufacturing industry by coagulation, Journal of Zhejiang
University Science A. Suppl. II, 340344.

Zollinger, H. 1991. Color Chemistry, Synthesis, Properties and Application of Organic Dyes and Pigments, VCH New York, 92-102.

\section{How to cite this article:}

Ramesh S. Masarbo. 2016. Decolorization of Sulfonated Azo Dye Methyl Orange by Bacterial Species. Int.J.Curr.Res.Aca.Rev.4(5): 172-178.

doi: http://dx.doi.org/10.20546/ijcrar.2016.405.017 